\title{
Linguistic Variation between Educated Community and Uneducated Community in Bangladesh
}

\author{
Sheikh Md. Muniruzzaman \\ Senior Lecturer, Department of English, Leading University, Sylhet-3100, Bangladesh
}

\begin{abstract}
The main purpose of this study was to explore the reasons of the variations in language use in terms of pronunciation, grammar, tone and word choice between educated and uneducated community. Though people have same Language Acquisition Device (LAD) and Universal Grammar, the language of a university teacher and a rickshaw puller is different. What is the role of innatism, behaviorism, and cognitive development here? The dominant factors for these linguistic variations are one's educational qualification, profession, financial condition, geographical location, cultural involvement, religious involvement, area of spending Critical Period, gender and reading newspaper that determine whether his/her language would be standard language or dialect. The nature of the study was mixed method and data collection tools were semi-structured interview schedule and observation schedule. Major findings showed that behaviorism is more dominant than innatism regarding language use.
\end{abstract}

Keywords: Innatist Theory, Behaviorist Theory, LAD, Universal Grammar, Standard Language and Dialect.

\section{Background of the Study}

"Yean tun khai jan"

The words and pronunciation of this line seem that it is Chinese or Arabic language. This phenomenon is amusing enough that this is our mother tongue Bangla. This is the dialect of Noakhali and its English meaning is 'dine at our place'. However, Yule (2006) argues that every language has many variations in the way in which it is spoken (p. 194). Holmes (2001) asserts that dialects are linguistic varieties that are characterized by their vocabulary, grammar and pronunciation and the speech of people categorizes them in different social and regional groups (p. 132).

Due to this variation many languages including Bangla has come to the point of extinction as someday and even today people find the dialects of Bangla not exactly the standard Bangla. Trudgill (2000) claims that "the diffusion of a linguistic feature through a society may be halted by barriers of social class, age, race, religion or other factors..." (p. 24). Fromkin, Rodman, Hyams (2003) propounds that similar to individuals, people from different groups speak the same language differently (p.445). Holmes (2001) argues that "Social factors such as age, status, gender, and region affect the rates of change and the direction in which the waves roll most swiftly...." (p. 200).

In Bangla, there are some words that are usually originated and used in the city areas first and then spread in rural areas, for instance: fatafati, jhakanaka (fantastic) etc. The grammatical differences that are found in the speeches of the two speakers give indication of their social background as different social groups use different linguistic varieties. Similarly, in Bangla it can be shown in the following way:

\section{Speaker A}

Kajta ami korsi

(I have done the work.)
Speaker B

Ami kajti koresi

(I have done the work.)
Spolsky (1998) maintains that "variety of a language used recognizably in a specific region or (a social dialect) by a specific social class" (p. 122). Bell (1976) argues that the variation between regional dialect and standard variety occurs in the phonological level (p. 57). Varshney (1985) notices that "People of different age, sex, social classes, occupations, or cultural groups in the same community will show variations in their speech" (p. 296). For instance: in Padma Nadir Majhi, a novel by Manik Banerjee, the language of the novelist himself and the language of the boatman Kuber, Gonesh, and Heru Jetha are characterized by standard language and regional dialect. These two types of speech that signify different education level and social standing: Novelist-"Ishwar bash koren oi vodro pollite...." (God dwells in that abode of riches.) and Hiru Jetha-"Tui to dehi kali kuthi Kubir, gora chad ailo kohan theika?" (You are dark Kubir. How has moonlight struck here?)

Meyerhoff (2013) argues that "Language can be a tool for negotiating and reflecting the relative importance of different social and personal qualities....the include a speaker's identification with different social groups, such as social class, friendship networks, gender and age." Britain (2013) stated that "Sociolinguistic variation is the study of the way language varies and changes in communities of speakers and concentrates in particular on the interaction of social factors (such as a speaker's gender, ethnicity, age, degree of integration into their community, etc.)..." According to Wardhaugh (2010), “...languages vary in many ways....speakers of a particular language sometimes speak different dialects of that language" (p. 138). Sometimes these dialects are quite different from the standard variety of that language. Similarly the dialects of Chittagong are unintelligible to great extent to the residents of Dhaka who speak standard Bangla. Thus linguistic variation is a significant phenomenon in language use and worthy of research and advanced study.

\section{Research Question}

The research questions were:

- What might be the possible reasons for this variation?

- Are there any ways to develop or change the situation? 


\section{Rationale of the Study}

This research is an authentic and interesting resource for the learners of linguistics. Different social and psychological aspects related to language use have been brought out in this research. Therefore, this study is a new source of literature for the professionals and for those who want to carry out further research on linguistic variation. Practically, it will benefit teachers, students, linguists and above all the users of Bangla.

\section{Methodology of the Study}

The researcher followed mixed method approach of research to conduct this study. The study areas were Chittagong, Feni, Noakhali, Faridpur, Rajbari, and Dhaka. Semistructured interview schedule and observation schedule were applied for data collection and collected data were analyzed thematically. This study incorporates 81 respondents- 17 from Chittagong, 5 from Feni, 20 from Noakhali, 10 from Faridpur, 9 from Rajbari and 20 from Dhaka. Data analysis framework of the study is as follows.

TABLE 1: DATA ANALYSIS FRAMEWORK

\begin{tabular}{|c|c|c|c|c|c|}
\hline Research Tools & Nature of Data & $\begin{array}{c}\text { Sample } \\
\text { Size }\end{array}$ & $\begin{array}{c}\text { Sampling } \\
\text { Procedure }\end{array}$ & Mode of Analysis & $\begin{array}{c}\text { Approach of } \\
\text { Analysis } \\
\end{array}$ \\
\hline $\begin{array}{l}\text { Semi-Structured } \\
\text { Interview Schedule }\end{array}$ & $\begin{array}{l}\text { Quantitative and } \\
\text { Qualitative }\end{array}$ & \multirow[t]{2}{*}{81} & Convenience & \multirow[t]{2}{*}{$\begin{array}{l}\text { Statistical Analysis (\%), } \\
\text { Organizing, Identifying }\end{array}$} & \multirow[t]{2}{*}{$\begin{array}{l}\text { Thematic } \\
\text { analysis }\end{array}$} \\
\hline Observation Schedule & Qualitative & & Purposive & & \\
\hline
\end{tabular}

\section{Data Analysis and Discussion}

Factor-1: Academic Qualification of the Respondents In formal education, the learners learn not only content but also standard language.

TABLE 2

\begin{tabular}{|c|c|c|c|c|}
\hline \multicolumn{5}{|c|}{$\begin{array}{l}\text { RESPONDENTS' ACADEMIC QUALIFICATION AND } \\
\text { LANGUAGE USE }\end{array}$} \\
\hline Qualification & \begin{tabular}{|c|} 
No. of \\
Respondents
\end{tabular} & $\begin{array}{c}\text { Percentage } \\
(\%)\end{array}$ & $\begin{array}{l}\text { Standard } \\
\text { Language } \\
(\%)\end{array}$ & $\begin{array}{l}\text { Regional } \\
\text { Dialect } \\
(\%)\end{array}$ \\
\hline $\begin{array}{c}\text { Post } \\
\text { Graduation } \\
\end{array}$ & \multirow{8}{*}{81} & 18.52 & 86.67 & 13.33 \\
\hline Graduation & & 27.16 & 86.36 & 13.64 \\
\hline HSC & & 12.35 & 80 & 20 \\
\hline SSC & & 14.81 & 66.67 & 33.33 \\
\hline Class 6-10 & & 11.11 & 77.78 & 22.22 \\
\hline Class 1-5 & & 12.35 & 50 & 50 \\
\hline Illiterate & & 3.7 & 33.33 & 66.67 \\
\hline Total & & $100 \%$ & 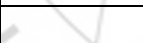 & 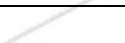 \\
\hline
\end{tabular}

Table 2 shows that the respondents who have a graduation or masters degree speak standard Bangla and their percentage is 86.67 and 86.36 respectively. It is seen that $13.33 \%$ respondents speak regional dialect having a post graduation degree and $13.64 \%$ respondents belong to the same class despite having a graduation degree. The percentages of standard language user decreases gradually when the academic qualification of the respondents goes one step downward. Among the respondents who are illiterate that means without any schooling, $33.33 \%$ of them use standard language and $66.67 \%$ of them use regional dialect. This is a clear indication that academic qualification has significant influence on the language use. This factor is closely related to B.F. Skinner's Behaviorist theory of language learning and Jean Piaget's theory of Cognitive Development.

\section{Factor-2: Profession of the Respondents}

Profession plays a vital role in the language of a person as he/she has to spend there more time than any other activity and mix with many people. This factor is related to B. F. Skinner's Behaviorist theory of language learning.
TABLE 3

\begin{tabular}{|c|c|c|c|}
\hline \multicolumn{4}{|c|}{ INFLUENCE OF PROFESSION ON LANGUAGE } \\
\hline Profession & $\begin{array}{c}\text { Percentage } \\
(\boldsymbol{\%})\end{array}$ & $\begin{array}{c}\text { Standard } \\
\text { Language (\%) }\end{array}$ & $\begin{array}{c}\text { Regional } \\
\text { Dialect (\%) }\end{array}$ \\
\hline BCS Cadre & 6.17 & 80 & 20 \\
\hline Teacher & 9.88 & 75 & 25 \\
\hline Student & 29.63 & 79.17 & 20.83 \\
\hline Doctor & 1.23 & 100 & 0 \\
\hline Service Holder & 7.41 & 83.33 & 16.67 \\
\hline MLSS & 9.88 & 75 & 25 \\
\hline Businessman & 20.99 & 64.71 & 35.29 \\
\hline Rickshaw puller & 2.47 & 0 & 100 \\
\hline Driver & 1.23 & 0 & 100 \\
\hline Hawker & 4.94 & 50 & 50 \\
\hline Laborer & 4.94 & 25 & 75 \\
\hline Unemployed & 1.23 & 0 & 100 \\
\hline Total & 100 & & \\
\hline
\end{tabular}

Table 3 shows that out of $6.17 \%$ BCS Cadres, $80 \%$ respondents speak standard Bangla and $20 \%$ speak regional dialect. Out of $9.88 \%$ teachers, $75 \%$ speak standard Bangla and $25 \%$ speak regional dialect; out of $29.63 \%$ students, $79.17 \%$ speak standard Bangla and $20.83 \%$ speak regional dialect. On the other hand, out of $2.47 \%$ rickshaw pullers, $100 \%$ speak regional dialect and out of $1.23 \%$ drivers, $100 \%$ speak regional dialect. Thus it can be argued that language of an individual educated or uneducated is greatly influenced by his/her profession.

\section{Factor-3: Family Income of the Respondents}

Family income defines one's social class whether he/she is in the upper class, middle class or lower class. 
International Journal of Science and Research (IJSR)

ISSN (Online): 2319-7064

Index Copernicus Value (2013): 6.14 | Impact Factor (2015): 6.391

TABLE 4

\begin{tabular}{|c|c|c|c|}
\hline \multicolumn{4}{|c|}{ INFLUENCE OF FAMILY INCOME ON LANGUAGE } \\
\hline $\begin{array}{c}\text { Monthly Income } \\
\text { Range (Taka) }\end{array}$ & $\begin{array}{c}\text { Percentage } \\
(\boldsymbol{\%})\end{array}$ & $\begin{array}{c}\text { Standard } \\
\text { Language (\%) }\end{array}$ & $\begin{array}{c}\text { Regional } \\
\text { Dialect (\%) }\end{array}$ \\
\hline Less than-10000 & 29.63 & 45.83 & 54.17 \\
\hline $11000-20000$ & 34.57 & 78.57 & 21.43 \\
\hline $21000-30000$ & 14.81 & 83.33 & 16.67 \\
\hline $31000-40000$ & 2.47 & 100 & 0 \\
\hline $41000-50000$ & 4.94 & 75 & 25 \\
\hline $51000-60000$ & 2.47 & 100 & 0 \\
\hline $61000-70000$ & 0 & 0 & 0 \\
\hline $71000-80000$ & 2.47 & 50 & 50 \\
\hline $81000-90000$ & 1.23 & 100 & 0 \\
\hline $91000-100000$ & 4.94 & 100 & 0 \\
\hline $101000-M o r e$ & 2.47 & 100 & 0 \\
\hline
\end{tabular}

This factor can be related to B. F. Skinner's Behaviorist theory of language learning. The last three percentages of Table 4 shows that those who have monthly income Tk. 80000 use standard language and its percentage is 100 . On the other hand, those who have monthly income below 10000 use regional dialect and its percentage is 54.17. So family income or economic solvency is an active catalyst of determining whether a person would use standard language or regional dialect.

\section{Factor-4: Father's Academic Qualification}

This can be related to both Chomsky's Innatist theory and B. F. Skinner's Behaviorist theory. Father's intellect is biologically transmitted into the child which supports the Innatist theory. On the other hand father's manner, mode of speaking are gradually followed and imitated by his child which supports Behaviorist theory.

\section{TABLE 5}

\begin{tabular}{|c|c|c|c|c|}
\hline \multicolumn{5}{|c|}{ INFLUENCE OF FATHER'S ACADEMIC QUALIFICATION } \\
\hline Qualification & $\begin{array}{l}\text { Total } \\
\text { No. }\end{array}$ & $\begin{array}{c}\text { Percentage } \\
(\%)\end{array}$ & $\begin{array}{c}\text { Standard } \\
\text { Language }(\%) \\
\end{array}$ & \begin{tabular}{|c} 
Regional \\
Dialect $(\%)$
\end{tabular} \\
\hline Post Grac & \multirow{8}{*}{81} & 9.88 & 87.5 & 12.5 \\
\hline Graduat & & 19.75 & 87.5 & 12.5 \\
\hline HSC & & 4.94 & 75 & 25 \\
\hline SSC & & 22.22 & 77.78 & 22.22 \\
\hline Class 6-10 & & 16.05 & 53.85 & 46.15 \\
\hline Class 1-5 & & 9.88 & 62.5 & 37.5 \\
\hline Illiterate & & 17.28 & $34.71>$ & 64.29 \\
\hline Total & & $100 \%$ & & \\
\hline
\end{tabular}

Table 5 shows that out of 81 respondents, there are $9.88 \%$ post graduate fathers whose offspring that means the respondents use standard language with the percentage of 87.5. Similarly, only $34.71 \%$ of the offspring of illiterate fathers use standard Bangla and the rest $64.29 \%$ use regional dialect. If their fathers were educated with graduation or post graduation degree, they would obviously use standard Bangla.

\section{Factor-5: Mother's Academic Qualification}

This item is also closely related to Innatist and Behaviorist theory like father's academic qualification. Normally, a child spends more time with mother than father.
TABLE 6

\begin{tabular}{|c|c|c|c|c|}
\hline \multicolumn{5}{|c|}{ INFLUENCE OF MOTHER'S ACADEMIC QUALIFICATION } \\
\hline Qualification & $\begin{array}{l}\text { Total } \\
\text { No. }\end{array}$ & $\begin{array}{c}\text { Percentage } \\
(\%)\end{array}$ & $\begin{array}{c}\text { Standard } \\
\text { Language }(\%)\end{array}$ & $\begin{array}{c}\text { Regional } \\
\text { Dialect (\%) }\end{array}$ \\
\hline Post Graduation & \multirow{8}{*}{81} & 1.23 & 100 & 0 \\
\hline Graduation & & 4.94 & 100 & 0 \\
\hline HSC & & 11.11 & 66.67 & 33.33 \\
\hline SSC & & 13.58 & 81.82 & 18.18 \\
\hline Class 6-10 & & 16.05 & 76.92 & 23.08 \\
\hline Class 1-5 & & 30.87 & 68 & 32 \\
\hline Illiterate & & 22.22 & 44.44 & 55.56 \\
\hline Total & & $100 \%$ & & \\
\hline
\end{tabular}

Table 6 shows that $100 \%$ respondents use standard Bangla whose mothers have a graduation or post graduation degree. On the other hand, 55.56\% respondents use regional dialect whose mothers are illiterate. Another vital point is that, $87.5 \%$ respondents those who have post graduate or graduate fathers use standard Bangla. But $100 \%$ respondents speak standard language who have graduate or post graduate mothers. So regarding child's language use mothers' academic qualification is more dominant than fathers'.

Factor-6: Geographical Location-based Analysis This factor is closely related to B. F. Skinner's Behaviorist theory and Jean Piaget's theory of Cognitive Development.

TABLE 7

\begin{tabular}{|c|c|c|c|c|}
\hline \multicolumn{5}{|c|}{$\begin{array}{l}\text { INFLUENCE OF GEOGRAPHICAL LOCATION ON } \\
\text { LANGUAGE }\end{array}$} \\
\hline Location & $\begin{array}{c}\text { Percentage } \\
(\%)\end{array}$ & $\begin{array}{c}\text { Standard } \\
\text { Language } \\
(\%)\end{array}$ & $\begin{array}{c}\text { Regional } \\
\text { Dialect } \\
(\%)\end{array}$ & $\begin{array}{c}\text { Total } \\
\text { No. }\end{array}$ \\
\hline Chittagong & 20.99 & 64.71 & 35.29 & \multirow{6}{*}{81} \\
\hline Feni & 6.17 & 60 & 40 & \\
\hline Noakhali & 24.69 & $\begin{array}{r}60 \\
\end{array}$ & 40 & \\
\hline Faridpur & 12.35 & 70 & 30 & \\
\hline Rajbari & 11.11 & 66.67 & 33.33 & \\
\hline Dhaka & 24.69 & 80 & 20 & \\
\hline
\end{tabular}

Table 7 shows that $20.99 \%$ respondents are from Chittagong and out of them $64.71 \%$ speak standard Bangla and $35.29 \%$ speak regional dialect. $24.69 \%$ respondents are from Dhaka and out of these respondents, $80 \%$ speak standard Bangla and $20 \%$ speak regional dialect. So it is evident that the percentage of standard Bangla speakers in Dhaka is greater than other areas.

\section{Factor-7: Area-based Analysis}

This is also related to Behaviorist theory and theory of Cognitive Development. Out of 81 respondents, 69.14 percent's house is in the city and 30.86 percent's house is in village. Out of this $69.14 \%$ city people, $71.43 \%$ speak standard Bangla and $28.57 \%$ speak regional dialect. On the contrary, out of $30.86 \%$ village people, $60 \%$ speak standard Bangla and $40 \%$ speak dialect. So it is clear that the city people have one advantage of using standard language than the village people.

\section{Factor-8: Critical Period Area-based Analysis}

This factor is closely related to Chomsky's Innatist theory. The place, city or village where a child spends its $1-13$ years gives a shape on its language. Out of 81 respondents, $53.09 \%$ have spent their CP in city. Out of these 


\section{International Journal of Science and Research (IJSR) \\ ISSN (Online): 2319-7064}

Index Copernicus Value (2013): 6.14 | Impact Factor (2015): 6.391

respondents, $76.74 \%$ use standard Bangla and $23.26 \%$ use regional dialect. On the other hand, $46.91 \%$ respondents have spent their $\mathrm{CP}$ in village. Out of these respondents, $57.89 \%$ use standard Bangla and $42.11 \%$ use regional dialect. This percentage variation shows that respondents who have spent $\mathrm{CP}$ in the city have extra advantage in case of language quality over those who spent $\mathrm{CP}$ in village.

Factor-9: Gender-based Analysis

It is related to Chomsky's Innatist theory. Out of 81 respondents, $74.07 \%$ are male and $25.93 \%$ are female. Data analysis shows that $65 \%$ male use standard Bangla and $35 \%$ of them use dialect. On the other hand, $76.19 \%$ female use standard Bangla and $23.81 \%$ use dialect. So it is a clear indication that the number of female is greater than the number of male as speakers of standard Bangla.

\section{Factor-10: Religion-based Analysis}

This factor can be related to B. F. Skinner's Behaviorist theory and Jean Piaget's theory of Cognitive Development. Out of 81 respondents, $87.65 \%$ are from Islam and $12.35 \%$ are from Hindu. 66.2\% Muslim speakers speak standard Bangla and $33.8 \%$ speak dialect. On the other hand, $80 \%$ Hindu speakers use standard Bangla and 20\% use dialect. It shows that the Hindu speakers use standard Bangla more than the Muslim speakers.

\section{Factor-11: Watching Television}

An uneducated person without formal schooling can learn standard Bangla if he/she regularly watches educative programs on television. Thus it is related to Behaviorist theory of language learning. Table 8 shows that $80 \%$ of the respondents use standard Bangla and they watch television more than two hours per day and $20 \%$ speak dialect of the same category.

TABLE 8

\begin{tabular}{|c|c|c|c|}
\hline \multicolumn{5}{|c|}{ INFLUENCE OF WATCHING TELEVISION ON } \\
LANGUAG \\
\hline $\begin{array}{c}\text { Range of } \\
\text { Watching } \\
\text { (Minutes) }\end{array}$ & $\begin{array}{c}\text { Percentage } \\
(\boldsymbol{\%})\end{array}$ & $\begin{array}{c}\text { Standard } \\
\text { Language } \\
(\boldsymbol{\%})\end{array}$ & $\begin{array}{c}\text { Regional } \\
\text { Dialect } \\
(\boldsymbol{\%})\end{array}$ \\
\hline Less than-20 & 8.64 & 71.43 & 28.57 \\
\hline $21-30$ & 18.52 & 73.33 & 26.67 \\
\hline $31-60$ & 30.87 & 84 & 16 \\
\hline $61-90$ & 6.17 & 60 & 40 \\
\hline $91-120$ & 17.28 & 64.29 & 35.71 \\
\hline $121-$ More & 12.35 & 80 & 20 \\
\hline None & 6.17 & 20 & 80 \\
\hline
\end{tabular}

On the other hand, $71.43 \%$ respondents use standard Bangla who watch television for 20 minutes or less per day. So it is evident that watching television has significant effect on their language quality.

\section{Factor-12: Reading Newspaper}

By reading newspaper regularly an uneducated or less educated and of course an educated person can learn standard Bangla. This is also related to Behaviorist theory of language learning.
TABLE 9

\begin{tabular}{|c|c|c|c|}
\hline \multicolumn{4}{|c|}{ INFLUENCE OF READING NEWSPAPER ON LANGUAGE } \\
\hline $\begin{array}{c}\text { Range of Reading } \\
\text { (Minutes) }\end{array}$ & $\begin{array}{c}\text { Percentage } \\
(\mathbf{\%})\end{array}$ & $\begin{array}{c}\text { Standard } \\
\text { Language } \mathbf{( \% )}\end{array}$ & $\begin{array}{c}\text { Regional Dialect } \\
(\mathbf{\%})\end{array}$ \\
\hline Less than-20 & 20.99 & 76.47 & 23.53 \\
\hline $21-30$ & 23.46 & 78.95 & 21.05 \\
\hline $31-60$ & 24.69 & 80 & 20 \\
\hline $61-90$ & 7.41 & 83.33 & 16.67 \\
\hline $91-120$ & 3.70 & 100 & 0 \\
\hline 121-More & 4.94 & 75 & 25 \\
\hline Non Reader & 14.81 & 41.67 & 58.33 \\
\hline \multicolumn{2}{|r}{} \\
\hline
\end{tabular}

Table 9 shows that $100 \%$ respondents speak standard Bangla out of those respondents who read newspaper for two hours per day. So it is evident that language quality is greatly influenced by reading newspaper.

\section{Factor-13: Religious Involvement}

Religious preaching, attending religious congregation, reciting the holy books of religion promote one's language use. This factor is related to both Behaviorist theory and theory of Cognitive Development. Out of 81 respondents, $28.4 \%$ respondents pray regularly and out of them $69.57 \%$ speak standard Bangla and $30.43 \%$ speak regional dialect. $61.73 \%$ respondents pray sometimes and out of them $64 \%$ speak standard Bangla and $36 \%$ speak regional dialect. $8.64 \%$ respondents attend religious congregation and out of them $85.71 \%$ speak standard Bangla and only $14.29 \%$ speak regional dialect. So it is evident that religious involvement promotes one's language quality to large extent.

\section{Factor-14: Cultural Involvement}

This factor is also related to both Behaviorist theory and theory of Cognitive Development. Out of 81 respondents, $69.14 \%$ are involved in cultural programs and activities and $30.86 \%$ are not involved. Those who are involved in cultural activities, among them $76.79 \%$ speak standard Bangla and $23.21 \%$ speak regional dialect. On the contrary, those who are not involved among them $48 \%$ speak standard Bangla and $52 \%$ speak regional dialect. It is a clear indication that cultural involvement promotes one's language quality.

\section{Factor-15: Listening Songs}

The language of the songs we listen comes out in the day to day conversation. Table 10 shows that $3.7 \%$ respondents like the songs of Momtaj and out of them $33.33 \%$ speak standard Bangla and $66.67 \%$ speak regional dialect.

\section{TABLE 10}

\begin{tabular}{|c|c|c|c|}
\hline \multicolumn{4}{|c|}{ INFLUENCE OF SONGS ON LANGUAGE } \\
\hline Type & $\begin{array}{c}\text { Percentage } \\
\mathbf{( \% )}\end{array}$ & $\begin{array}{c}\text { Standard } \\
\text { Language (\%) }\end{array}$ & $\begin{array}{c}\text { Regional } \\
\text { Dialect (\%) }\end{array}$ \\
\hline Momtaj & 3.7 & 33.33 & 66.67 \\
\hline Lalongity & 14.81 & 66.67 & 33.33 \\
\hline Robindrosongit & 34.57 & 85.71 & 14.29 \\
\hline Palligity & 8.65 & 42.86 & 57.14 \\
\hline Band & 17.28 & 71.43 & 28.57 \\
\hline English & 3.7 & 66.67 & 33.33 \\
\hline Hindi & 7.41 & 66.67 & 33.33 \\
\hline None & 9.88 & 37.5 & 62.5 \\
\hline \multicolumn{3}{|l}{} \\
\end{tabular}

$14.81 \%$ respondents like the songs of Lalon and out of them $66.67 \%$ speak standard language and $33.33 \%$ speak regional dialect. $34.57 \%$ respondents like Robindrosongit and out of 


\section{International Journal of Science and Research (IJSR) \\ ISSN (Online): 2319-7064}

Index Copernicus Value (2013): 6.14 | Impact Factor (2015): 6.391

them $85.71 \%$ speak standard Bangla and $14.29 \%$ speak regional dialect. This factor can be related to B. F. Skinner's Behaviorist theory of language learning. So it is clear that one's language use is influenced by the type of songs he/she listens.

\section{Findings and Recommendations}

\subsection{Findings}

a) In L1 acquisition, Behaviorist theory is more dominant than Innatist theory. All the respondents were born with same biological components but now their language is different that makes it evident that Behaviorist theory is more active than Innatist theory in case of language use.

b) Uneducated people might use regional dialect all the time but educated community usually does not make use of the standard language all the time.

c) Without practice and nurture the language of educated people gradually loses the standard quality whereas regular study enhances the language quality of an uneducated person.

d) In case of child's language use, mother' academic qualification is more dominant than father's as a child spends more time with its mother than father. So mother's language use influences the child's language more than father's language use.

e) The number of female is greater than the number of male as speakers of standard Bangla.

f) The number of Hindu speakers of standard Bangla is more than the number of Muslim speakers.

g) Reading Bangla newspaper regularly, watching television programs, listening songs with standard Bangla promote one's language quality.

h) Speakers who have spent Critical Period in city have extra benefit in case of language quality over those who spent Critical Period in village. Language learnt till 13 years influences the language of an individual over his/her whole life.

i) The language of an individual is influenced to great extent by the language quality of siblings. This individual can be uneducated or less educated but if the siblings are educated and use standard language, it greatly promotes his/her language quality.

j) Family income that means economic solvency is an active catalyst of determining whether a person would use standard language or regional dialect.

k) The language of an individual is influenced to some extent by the language of neighbor. An uneducated person living with educated neighbors can learn and use standard language in their day to day life.

1) The language of an individual is influenced by the language of close friends. Friends usually share their leisure together and while doing so one's language affects other's language.

m) People living in cities have one advantage of using standard language than the village people. All the academic and administrative institutions are located in the city areas which have certain influence on the language of the people living in the cities.

n) Religious involvement and cultural involvement promote one's language quality to large extent. Religious preaching, scriptures, attending in cultural programs gradually influence one's language quality.

o) The number of standard Bangla speakers in Dhaka is greater than other areas. That means more people in Dhaka speak standard language than other districts.

p) The language of an individual educated or uneducated is greatly influenced by his/her profession. An individual can be an MLSS with less education, but mixes with educated bosses which greatly affects his/her language.

\subsection{Recommendations}

\subsubsection{For Institution}

a) The government and the stakeholder could urge the media to broadcast programs highlighting the significance of using standard Bangla. Besides, the print media could promote this sentiment using different supplements, reports, editorial columns, jokes etc.

b) Media could convey message through advertisements that would raise the awareness of using standard Bangla. This advertisement can be sponsored by Bangla Academy, International Mother Language Institute and different NGOs.

c) As Bangla is our mother tongue, every institution both government and non-government might make the standard use of Bangla mandatory and monitor the language being used by the employees and their subordinates.

d) Educational institutions might pay attention to learners' language use as well as teachers'. The executive committee can make some rules regarding this to ensure the use standard Bangla by the teachers, the learners and even the staff in the campus.

e) The recruiting agencies need to pay attention to the language use of the employees being recruited.

f) In admission tests, educational institutions could allot a specific percentage of score on the use of standard Bangla.

\subsubsection{For Individual}

a) Teachers might use standard Bangla as learners follow their teachers' language. The speaking style of the teachers influences the speaking style of the learners.

b) Parents might take care of the quality of Bangla language use of their children especially till 13 years. In some cases this period can be up to 17 years.

c) People might watch educative television programs including news as well as movies with standard Bangla and follow the pronunciation.

d) People might listen to radio programs as well to enhance their language quality. This will certainly promote their pronunciation.

e) People might read Bangla newspaper regularly which promotes quality of language. This will increase the range of vocabulary, syntactic quality etc.

f) People might listen to songs with standard Bangla that also enhances their use of language. According to Suggestopedia proposed by Lozanov (1978), learning becomes more effective and longer lasting if it is done through music.

g) People might engage themselves in cultural programs and activities for enhancing their language quality. 


\section{Conclusion}

Linguistic variation is ever present in all languages of the world. It is expected that the institutions concerned and individuals would follow the earlier mentioned recommendations. As Bangla is our mother tongue, we might read, write and speak standard Bangla to uphold its prestige. So we might say:

\section{"Ekhan theke kheye jan"}

(Dine at our place.)

\section{References}

[1] Anonymous, A Comparative Study between Standard Bengali Language and the Regional Dialect of Bogra in Bangladesh, Unpublished master's thesis, Jahangirnagar University, Savar, Dhaka, Bangladesh, 2011

[2] Anonymous, Attitude towards Language Variation in Bangladesh, Unpublished master's thesis, Jahangirnagar University, Savar, Dhaka, Bangladesh, 2010

[3] Anonymous, Language Variation and Textual Categorisation. Retrieved March 31, 2013, from http://lvtcuvigo.blogspot.com/

[4] B. Spolsky, Sociolinguistics, Oxford University Press, 122pp, 1998

[5] D. Britain, Sociolinguistic variation, Retrieved March 31, 2013, from http://www.llas.ac.uk/resources/gpg/1054

[6] G. Yule, The Study of Language, ISBN: 978-0-52174024-1, Cambridge University Press, $3^{\text {rd }}$ ed., 194pp, 18,2006

[7] J. Holmes, An Introduction to Sociolinguistics, Pearson Education, $2^{\text {nd }}$ ed., $132 \mathrm{pp}, 2001$

[8] K. F. Tonny, An investigation into the field of language variation in the verbal communication of the students and teachers in English medium schools, Unpublished master's thesis, Jahangirnagar University, Savar, Dhaka, Bangladesh, 2012

[9] Meyerhoff, Miriam. (2013). Sociolinguistic Variation and Change. Retrieved March 31, 2013, from http://www.eolss.net/Sample-Chapters/C04/E6-91-0601.pdf

[10]P. Trudgill, Sociolinguistics: An Introduction to Language and Society, Penguin Books, $4^{\text {th }}$ ed., 24pp, 2000

[11]R. A. Hudson, Sociolinguistics, Cambridge University Press, $2^{\text {nd }}$ ed.

[12] R. L. Varshney, An Introductory Textbook of Linguistics and Phonetics, ISBN: GP-001287, BOC Ltd., $15^{\text {th }}$ ed., 296pp, 20, 1985

[13]R. T. Bell, Sociolinguistics: Goals, Approaches, and Problems, St. Martin's Pess, 57pp, 1976

[14]R. Wardhaugh, An Introduction to Sociolinguistics, Wiley-Blackwell, $6^{\text {th }}$ ed., 138pp, 2010

[15] V. Fromkin, R. Rodman \& N. Hyams, An Introduction to Language, Thomson Wadsworth, $7^{\text {th }}$ ed., 445pp, 2003

[16] Virtual Bangladesh: Bangla. Retrieved March 31, 2013, from http://www.virtualbangladesh.com/bd_bangla.html 